\title{
PENGARUH INFLASI DAN PERTUMBUHAN EKONOMI TERHADAP TINGKAT KEMISKINAN DI INDONESIA
}

\author{
Oleh: \\ Rudy Susanto ${ }^{1}$ \\ Indah Pangesti ${ }^{2}$ \\ Program Studi Pendidikan Ekonomi \\ Fakultas Ilmu Pendidikan dan Pengetahuan Sosial \\ Universitas Indraprasta PGRI \\ Email: \\ rudy.susanto19@gmail.com \\ esthicute@gmail.com
}

\begin{abstract}
In the economic theory, inflation has an influence on the level of poverty, but the results of the analysis of this study indicate that inflation has no effect on the level of poverty based on research data for 2000-2019 obtained from the Central Statistics Agency. This study aims to determine and analyze the effect of inflation and economic growth on poverty levels in Indonesia. The research method used is descriptive quantitative using secondary data and data analysis methods are linear regression analysis, correlation analysis, determination analysis, and hypothesis testing. The results showed that inflation has no effect on the level of poverty due to the value of $t_{\text {count }}<t_{\text {table }}$, but economic growth has a significant effect on the poverty level because the value of $t_{\text {count }}>t_{\text {table. Inflation and Economic Growth }}$ simultaneously have a significant effect on the Poverty Level as indicated by the value of $F_{\text {count }}>F_{\text {table }}$.
\end{abstract}

Keywords: Inflation, Economic Growth, Poverty Level. 


\begin{abstract}
ABSTRAK
Pada teori ekonomi inflasi mempunyai pengaruh terhadap tingkat kemiskinan, tetapi hasil analisis penelitian ini menunjukkan bahwa inflasi tidak berpengaruh terhadap tingkat kemiskinan bedasarkan data penelitian tahun 2000-2019 yang diperoleh dari Badan Pusat Statistik. Penelitian ini bertujuan untuk mengetahui dan menganalisis pengaruh inflasi dan pertumbuhan ekonomi terhadap tingkat kemiskinan di Indonesia. Metode penelitian yang digunakan adalah deskriptif kuantitatif dengan menggunakan data sekunder dan metode analisis datanya dengan analisis regresi linear, analisis korelasi, analisis determinasi, dan uji hipotesis. Hasil penelitian menunjukkan bahwa Inflasi tidak mempunyai pengaruh terhadap Tingkat Kemiskinan dikarenakan nilai $t_{\text {hitung }}<t_{\text {tabel}}$, tetapi Pertumbuhan Ekonomi mempunyai pengaruh yang signifikan terhadap Tingkat Kemiskinan dikarenakan nilai thitung $>t_{\text {tabel. }}$. Inflasi dan Pertumbuhan Ekonomi secara simultan memiliki pengaruh yang signifikan terhadap Tingkat Kemiskinan yang ditunjukkan oleh nilai $\mathrm{F}_{\text {hitung }}>\mathrm{F}_{\text {tabel }}$.
\end{abstract}

Kata Kunci: Inflasi, Pertumbuhan Ekonomi, Tingkat Kemiskinan

\title{
A. PENDAHULUAN
}

Inflasi merupakan kenaikan harga barang kebutuhan pokok rumah tangga secara terus-menerus. Data mengenai kenaikan harga-harga kebutuhan pokok ini dicatat oleh Badan Pusat Statistik (BPS). Indikator inflasi ini dibuat oleh para ahli yang disebut dengan Indeks Harga Konsumen (IHK).

Secara historis inflasi Indonesia lebih tinggi dibandingkan dengan negaranegara berkembang lainnya, seperti Thailand, Malaysia, dan sebagainya. Negaranegara ASEAN mengalami inflasi antara 3\% sampai 5\% pada periode tahun 20052014. Sedangkan Indonesia tingkat rata-rata inflasi setahun sebesar 8,5\% dalam periode yang sama. Salah satu penyebabnya adalah Indonesia mengimpor bahan bakar minyak. Apabila harga bahan bakar mengalami kenaikan, menyebabkan biaya transportasi akan naik (seperti: angkot, bis, taksi, dan transportasi lainnya) dan biaya-biaya lainnya juga akan mengalami kenaikan.

Pertumbuhan ekonomi adalah terminologi untuk menyatakan ekspansi kapasitas produksi suatu perekonomian yang merupakan hasil output yang dibentuk oleh berbagai sektor ekonomi, sehingga dapat dilihat bagaimana kemajuan atau kemunduran yang telah dicapai di sektor ekonomi pada kurun waktu tertentu. (Todaro, 2011). Pertumbuhan ekonomi merupakan ukuran untuk keberhasilan pembangunan suatu negara, dimana hasilnya dapat dinikmati oleh masyarakat. (Astria, 2014).

Suatu negara dipandang berhasil atau tidak dalam memecahkan permasalahan ekonomi negaranya sendiri dapat dilihat dari ekonomi makro dan mikro negara tersebut. Apabila inflasi meningkat, maka tingkat kesejahteraan menjadi terganggu, yakni daya beli masyarakat menurun. Salah satu indikator ekonomi makro yang digunakan untuk melihat/mengukur stabilitas perekonomian suatu negara adalah tingkat kesejahteraan masyarakat, dimana kesejahteraan masyarakat ini dapat digunakan untuk mengukur tingkat kemiskinan. 
Untuk mengukur tingkat kemiskinan di Indonesia digunakan konsep kemampuan untuk memenuhi kebutuhan dasar (basic need approach). Dengan pendekatan ini kemiskinan dipandang sebagai ketidakmampuan dari sisi ekonomi untuk memenuhi kebutuhan dasar makanan dan bukan makanan (pakaian dan sebagainya) yang bersifat mendasar. Penduduk miskin adalah penduduk yang memiliki rata-rata pengeluaran per orang (perkapita) per bulan di bawah garis kemiskinan. Pengukuran kemiskinan dengan menggunakan konsep kemampuan memenuhi kebutuhan dasar tidak hanya digunakan oleh Indonesia, tetapi digunakan juga oleh negara-negara lain, seperti: Amerika, Pakistan, Bangladesh, Vietnam, dan Gambia. Bank dunia mempunyai alat ukur kemiskinan dengan melihat kemampuan membeli (daya beli) US\$ 2 per hari.

Kemiskinan dapat juga dilihat dari dimensi lain, yakni dilihat dari ketidakcukupan untuk kesehatan, nutrisi dan pendidikan. Di bidang pendidikan, tingkat buta huruf dapat digunakan untuk mengukur garis kemiskinan. Indeks kesejahteraan komposif sebagai alternatif selain penggunaan dimensi tunggal, yakni dari aspek ekonomi semata-mata, dapat dilakukan kombinasi dari pengeluaran konsumsi (ekonomi), kesehatan dan pendidikan. Konkritnya mengkombinasikan penghasilan, kesehatan dan pendidikan.

Data tentang kemiskinan dan garis kemiskinan di Indonesia telah dihitung oleh Badan Pusat Statistik (BPS) terakhir untuk tahun 2019. Data tersebut meliputi: Nasional, Propinsi, Kota, dan Kabupaten. Data tersebut dihitung menurut jumlah orang miskin, persentase orang miskin dan garis kemiskinan di tiap provinsi dan kota atau kabupaten.

\section{B. KAJIAN PUSTAKA}

\section{Inflasi}

Inflasi adalah suatu keadaan dimana tingkat harga secara umum (price level) cenderung meningkat. Penyebab inflasi itu adalah kenaikan permintaan melebihi penawaran atau di atas kemampuan berproduksi yang menyebabkan harga menjadi naik (demand pull inflation), inflasi juga dapat terjadi atau datang dari sisi penawaran, yakni kenaikan biaya produksi sehingga harga naik (cost push inflation). (Sukanto, 2015).

Selain itu inflasi dapat juga terjadi karena harga barang-barang meningkat sedangkan tingkat upah masyarakat tetap. (Sari \& Natha, 2016).

Pada teori inflasi dijelaskan bahwa inflasi terjadi karena jumlah uang yang beredar tidak seimbang dengan barang tersedia (teori kuantitatif uang) dan masyarakat ingin berada di luar batas kemampuan ekonominya (teori Keynes). (Sukirno, 2015).

\section{Pertumbuhan Ekonomi}

Pertumbuhan ekonomi merupakan hasil output yang dibentuk oleh berbagai sektor ekonomi sehingga dapat dilihat bagaimana kemajuan atau kemunduran yang telah dicapai sektor ekonomi pada kurun waktu tertentu. (Arsyad, 2010)

Pertumbuhan ekonomi yang tinggi dapat meningkatkan kapasitas ekonomi 
(Produk Domestik Bruto/PDB) sehingga dapat menurunkan tingkat kemiskinan, tetapi ketimpangan pendapatan dapat menghambat efektivitas pertumbuhan ekonomi dalam menurunkan tingkat kemiskinan. (Dewanto et al., 2014).

Tingkat pertumbuhan ekonomi harus berjalan secara beriringan dan terencana, dengan mengupayakan terciptanya pemerataan kesempatan dan pembagian hasilhasil pembangunan dengan lebih merata, sehingga hasilnya dapat dinikmati oleh masyarakat sampai lapisan paling bawah. (Nyoman \& Setya Ari Wijayanti, 2014).

Teori pertumbuhan ekonomi menjelaskan, bahwa pertumbuhan ekonomi dipengaruhi oleh jumlah penduduk, barang-barang modal, luas tanah dan kekayaan alam (teori pertumbuhan Klasik), selain itu peranan pengusaha sangat penting untuk mewujudkan pertumbuhan ekonomi (teori Schumpeter), serta diperlukan pembentukan modal yang digunakan secara efektif agar tercapai pertumbuhan ekonmi yang teguh/steady growth (teori Harrod-Domar) (Todaro, 2011).

\section{Tingkat Kemiskinan}

Kemiskinan merupakan masalah klasik yang telah ada sejak manusia itu ada. Kemiskinan itu berwajah banyak dan akan terus menjadi persoalan dari masa ke masa. Kemiskinan adalah suatu masalah yang kompleks yang dipengaruhi oleh berbagai faktor yang saling berkaitan, seperti: tingkat pendapatan, pendidikan, akses terhadap barang dan jasa, lokasi, geografis, gender dan kondisi lingkungan. (Hambarsari \& Inggit, 2016).

Kemiskinan adalah suatu kondisi kehidupan dimana terdapat sejumlah penduduk tidak mampu mendapatkan sumber daya yang cukup untuk memenuhi kebutuhan pokok (basic needs) minimum dan mereka hidup di bawah tingkat kebutuhan minimum tersebut, nilai kebutuhan dasar minimun tersebut digambarkan dengan garis kemiskinan. (Imelia, 2012).

Kemiskinan muncul karena adanya ketimpangan distribusi pendapatan, adanya perbedaan kualitas sumber daya manusia yang menyebabkan adanya perbedaan pada tingkat upah, serta adanya perbedaan dalam pemenuhan modal, sehingga kemiskinan dapat digambarkan pada teori lingkaran kemiskinan. (Imelia, 2012).

Pada dasarnya terdapat dua sisi kemiskinan, yaitu kemiskinan yang dilihat dari tingkat pendapatan dan kebutuhan pokok (dasar minimum) untuk seseorang dapat hidup dengan layak (kemiskinan absolut) dan kemiskian yang terjadi karena adanya ketimpangan sosial dimana seseorang sudah dapat memenuhi kebutuhan pokoknya tetapi masih dibawah kondisi masyarakat sekitarnya (kemiskinan relatif). (Windra et al., 2016).

Di dalam teori kemiskinan dijelaskan, bahwa kemiskinan merupakan persoalan individual yang disebabkan oleh kelemahan dan pilihan individu yang bersangkutan (teori Neo Liberal dari Shanon et. al) dan masyarakat menjadi miskin karena adanya budaya kemiskinan dengan karakter, apatis, kurang usaha, hanya menyerah pada nasib, sistem keuangan yang tidak mantap, kurang pendidikan, kurang ambisi untuk membangun masa depan, kesejahteraan dan kekerasan banyak terjadi (teori Marjinal dari Lewis) (Todaro, 2011). 


\section{METODE PENELITIAN}

Data penelitian diperoleh dari Badan Pusat Statistik (BPS) tahun 2000-2019. Tipe data yang dianalisis adalah time series dengan variabel penelitiannya adalah Inflasi, Pertumbuhan Ekonomi, dan Tingkat Kemiskinan. Data penelitian tersebut dianalisis dengan menggunakan analisis regresi liner sederhana, regresi linier berganda, koefisien korelasi sederhana, koefisien korelasi berganda, koefisien determinan, serta analisis hipotesis dengan uji t dan uji f. (Supardi, 2013).

\section{HASIL DAN PEMBAHASAN}

Tabel 1.

Data Inflasi, Pertumbuhan Ekonomi dan Tingkat Kemiskinan di Indonesia Tahun 2000 - 2019

\begin{tabular}{cccc}
\hline TAHUN & $\begin{array}{c}\text { INLASI } \\
(\boldsymbol{\%})\end{array}$ & $\begin{array}{c}\text { PERTUMBUHAN } \\
\text { EKONOMI } \\
(\boldsymbol{\%})\end{array}$ & $\begin{array}{c}\text { TINGKAT } \\
\text { KEMISKINAN }\end{array}$ \\
\hline 2000 & 9,40 & 4,92 & 19,14 \\
2001 & 12,55 & 3,64 & 18,41 \\
2002 & 10,03 & 4,50 & 18,20 \\
2003 & 5,16 & 4,78 & 17,42 \\
2004 & 6,40 & 5,13 & 16,65 \\
2005 & 17,11 & 5,69 & 15,97 \\
2006 & 6,60 & 5,50 & 17,75 \\
2007 & 6,59 & 6,35 & 16,58 \\
2008 & 11,06 & 6,01 & 15,42 \\
2009 & 2,78 & 4,63 & 14,15 \\
2010 & 6,96 & 6,22 & 13,33 \\
2011 & 3,79 & 6,49 & 12,36 \\
2012 & 4,30 & 6,26 & 11,66 \\
2013 & 8,38 & 5,78 & 11,47 \\
2014 & 8,36 & 5,02 & 10,96 \\
2015 & 3,30 & 4,79 & 11,96 \\
2016 & 3,02 & 5,02 & 10,70 \\
2017 & 3,61 & 5,07 & 14,98 \\
2018 & 3,13 & 5,17 & 13,91 \\
2019 & 2,62 & 5,02 & 13,25 \\
\hline Sumber $:(B P S, 2020 \mathrm{c})$ & $;(B P S, 2020 \mathrm{~b}) ;(\mathrm{BPS}, 2020 \mathrm{a})$ \\
\hline
\end{tabular}

Bedasarkan data penelitian yang tertera pada tabel di atas, menunjukan arah perubahan antara Inflasi terhadap Tingkat Kemiskinan adalah postif dengan persamanan regresi linier $\mathrm{Y}=12,49+0,33 \mathrm{X}_{1}$. Inflasi mempunyai hubungan yang positif dengan Tingkat Kemiskinan, dimana tingkat hubungan itu dalam kategori rendah dengan nilai koefisien korelasi sebesar 0,34. Kontribusi yang diberikan oleh Inflasi terhadap Tingkat Kemiskinan sebesar sebesar 11,56\% dan sisanya sebesar $88,44 \%$ adalah kontribusi faktor lain. Hasil analisis hipotesis menujukkan nilai $t_{\text {hitung }}<t_{\text {tabel }}$ atau $1,534<1,734$, maka $\mathrm{H}_{0}$ diterima dan $\mathrm{H}_{1}$ ditolak yang berarti tidak terdapat pengaruh yang signifikan antara Inflasi terhadap Tingkat Kemiskinan. Hal ini dikarenakan adanya kebijakan pemerintah untuk memberikan subsidi atau bantuan kepada masyarakat. 
Untuk Pertumbuhan Ekonomi memiliki arah perubahan negatif terhadap Tingkat Kemiskinan dengan persamaan regresi liniernya $\mathrm{Y}=19,66-1,28 \mathrm{X}_{2}$. Persamaan ini menunjukan antara Pertumbuhan Ekonomi adalah negatif. Hubungan antara Pertumbuhan Ekonomi dengan Tingkat Kemiskinan dalam kategori kuat dengan nilai koefisien korelasi sebesar nilai 0,68. Pertumbuhan Ekonomi memberikan kontribusi terhadap Tingkat Kemiskinan sebesar sebesar 46,24\% dan sisanya sebesar 53,76\% adalah kontribusi faktor lain. Dari hasil analisis hipotesis diperoleh nilai $t_{\text {hitung }}>\mathrm{t}_{\text {tabel }}$ atau 3,935 $>1,734$, maka $\mathrm{H}_{0}$ ditolak dan $\mathrm{H}_{2}$ diterima, hal ini menunjukan terdapat pengaruh yang signifikan antara Pertumbuhan Ekonomi terhadap Tingkat Kemiskinan, dikarenalan dengan meningkatnya pertumbuhan ekonomi akan banyak tercipta lapangan pekerjaan yang dapat menyerap tenaga kerja, sehingga tingkat kemiskinan akan berkurang.

Secara simultan diperoleh persamaan regresi linier berganda $Y=18,86+$ $0,32 X_{1}-1,19 X_{2}$. Dari persamaan tersebut dapat dilihat bahwa perubahan yang terjadi pada Tingkat Kemiskinan disebabkan adanya perubahan pada Inflasi dan Pertumbuhan Ekonomi secara simultan. Inflasi dan Pertumbuhan Ekonomi secara simultan mempunyai hubungan yang positif terhadap Tingkat Kemiskinan. Hubungan tersebuat termasuk ke dalam kategori kuat dengan nilai koefisien korelasi sebesar 0,69. Kontribusi yang diberikan oleh Inflasi dan Pertumbuhan Ekonomi secara simultan terhadap Tingkat Kemiskinan sebesar sebesar 47,61\% dan sisanya sebesar 52,39\% adalah kontribusi faktor lain. Hasil analisis hipotesis diperoleh nilai $F_{\text {hitung }}>\mathrm{F}_{\text {tabel }}$ atau 7,7305 > 3,59, sehingga $\mathrm{H}_{0}$ ditolak dan $\mathrm{H}_{3}$ diterima. Hal ini berarti terdapat pengaruh yang signifikan antara Inflasi dan Pertumbuhan Ekonomi secara simultan terhadap Tingkat Kemiskinan.

\section{E. SIMPULAN}

Inflasi tidak mempunyai pengaruh yang signifikan terhadap Tingkat Kemiskinan, hal ini dikarenakan nilai $t_{\text {hitung }}<t_{\text {tabel }}$ atau 0,7906 $<1,753$. Tetapi Pertumbuhan Ekonomi berpengaruh yang signifikan terhadap Tingkat Kemiskinan yang ditunjukan oleh nilai thitung $>t_{\text {tabel }}$ atau 3,4024 $>1,753$.

Terdapat pengaruh yang signifikan antara Inflasi dan Pertumbuhan Ekonomi secara simultan terhadap Tingkat Kemiskinan karena nilai $F_{\text {hitung }}>F_{\text {tabel }}$ atau $7,7305>3,59$. 


\section{DAFTAR PUSTAKA}

Arsyad, L. (2010). Ekonomi Pembangunan (5th ed.). STIM YKPN Yogyakarta.

Astria, S. A. (2014). Analisis Pengaruh Dana Alokasi Umum Dan Belanja Modal Terhadap Pertumbuhan Ekonomi Di Sumatera Selatan. Jurnal Ekonomi Pembangunan, 12(1), 41-54.

BPS. (2020a). Jumlah Penduduk Miskin, Persentase Penduduk Miskin dan Garis Kemiskinan, 1970-2017. https://www.bps.go.id/statictable/2014/01/30/1494/jumlah-pendudukmiskin-persentase-penduduk-miskin-dan-garis-kemiskinan-1970-2017.html

BPS. (2020b). Pertumbuhan PDRB Di Indonesia. https://www.bps.go.id/indicator/171/540/10/laju-pertumbuhan-pdrb-adhkonstan-menurut-pengeluaran-2010-100-.html

BPS. (2020c). Tingkat Inflasi Di Indonesia. https://www.bps.go.id/indicator/3/1/20/inflasi-umum-.html

Dewanto, P., Rujiman, \& Suriadi, A. (2014). Analisis Pengaruh Pertumbuhan Ekonomi Pengentasan Kemiskinan Di Kawasan Mebidangro. Jurnal Ekonomi, 17(3), 138-150.

Hambarsari, D. P., \& Inggit, K. (2016). Analisis Pengaruh Pertumbuhan Ekonomi, Pertumbuhan Penduduk dan Inflasi Terhadap Tingkat Kemiskinan Di Jawa Timur Tahun 2004-2014. 1(2), 257-282. https://www.mendeley.com/catalogue/23af5586-3185-3bda-85d70bb7c4761e6e/?utm_source=desktop

Imelia. (2012). Pengaruh Inflasi terhadap Kemiskinan di Propinsi Jambi. Jurnal Paradigma Ekonomika, 1 No. 5(1).

Nyoman, N., \& Setya Ari Wijayanti, N. L. K. (2014). Pengaruh Tinkat Inflasi, Laju Pertumbuhan Ekonomi Dan Upah Minimun Terhadap Tingkat Pengangguran Terbuka Di Provinsi Bali. E-Jurnal Ekonomi Pembangunan, 3(10), 460-466. http://ojs.unud.ac.id/index.php/eep/article/view/9393

Sari, N. A., \& Natha, K. S. (2016). Pengaruh Pertumbuhan Ekonomi, Pertumbuhan Penduduk, dan Inflasi terhadap Jumlah Penduduk Miskin di Provinsi Bali Periode 1999 - 2013. Jurnal Ekonomi Pembangunan Universitas Udayana, 5(12), 1493-1512.

Sukanto. (2015). Fenomena Inflasi, Penganguran dan Pertumbuhan Ekonomi di Indonesia: Pendekatan Kurva Philips dan Hukum Okun. Jurnal Ekonomi Pembangunan, 13(2), 96-106.

Sukirno, S. (2015). Makro Ekonomi, Teori Pengantar (Ke 3). PT. Raja Grafindo Persada.

Supardi. (2013). Aplikasi Statistik Dalam Penelitian “Konsep Statistika Yang Lebih Komprehensif" (Edisi Revi). PT. Prima Ufuk Semesta. 
Todaro, M. P. and S. C. S. (2011). Pembangunan Ekonomi Jilid 2 (11th ed.). Erlangga.

Windra, Marwoto, P. B., \& Rafani, Y. (2016). Analisis Pengaruh Inflasi, Pertumbuhan Ekonomi, Dan Tingkat Pengangguran Terhadap Kemiskinan Di Indonesia. Jurnal Progresif Manajemen Bisnis, 14(2), 19-27. 